\title{
PROLINE DEHYDROGENASE (PRODH) GENE POLYMORPHISMS AND THE RISK OF SCHIZOPHRENIA IN IRANIAN POPULATIONS
}

\author{
F. H. MOGHADAM $M^{1}$, Z. H. A. MEHRABANI', M. AMOUNAJAF', \\ S. RAHMANZADEH ${ }^{3}$, F. GHASEMVAND ${ }^{3}$, A. S. SAMGHABADI ${ }^{3}$, \\ A. NEJADMOGHADDAM ${ }^{3}$, E. OMIDINIA ${ }^{3 凶}$ \\ ${ }^{1}$ Department of Traditional Medicine, School of Traditional Medicine, \\ Shahid Beheshti University of Medical Sciences, Tehran, Iran; \\ ${ }^{2}$ Department of Clinical Biochemistry and Laboratory Medicine, \\ Tabriz University of Medical Sciences, Tabriz, Iran; \\ ${ }^{3}$ Enzyme Technology Lab., Genetics \& Metabolism Research Group, \\ Pasteur Institute of Iran, Tehran, Iran; \\ 凶e-mail: saeed_r81@yahoo.comor 2000.spss@gmail.com
}

Received: 10 August 2019; Accepted: 29 November 2019

Schizophrenia is a highly heritable mental disorder which can be occurred as a result of mutations or single nucleotide polymorphisms (SNPs) in various genes. Proline dehydrogenase (PRODH) gene is one of the most important genes which can be associated with increased risk of schizophrenia in several populations. Here, we considered the effect of PRODH gene polymorphisms on the incidence of schizophrenia in Iranian populations. This study was done using the analysis of 3 SNPs markers, including G1496A, G758A and C1482T. Molecular analysis was performed on 263 schizophrenic patients and 278 healthy individuals (control group). These examinations were executed by PCR-based restriction fragment length polymorphism (RFLP) technique. Statistical analysis was performed by SPSS software (16.0). Our findings showed that G1496A and C1482T polymorphisms in patients were significantly higher than controls and there were meaningful correlations between the occurrence of these polymorphisms and schizophrenia in the population $(P<0.001)$. However, there was no significant relationship between G758A in the PRODH gene and schizophrenia. Haplotype analysis showed that AAT, AAC and GAT blocks (variation alleles are bold) had significant correlations with schizophrenia. PRODH gene can be considered as one of the important genes involved in schizophrenia development among the Iranian population.

Ke y w ord s: proline dehydrogenase, gene polymorphism, RFLP, schizophrenia.

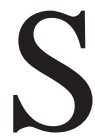
chizophrenia is a kind of mental and affective disorder with a frequency of about $1 \%$ in the world population [1]. The disease symptoms usually begin in adolescence and early adulthood; however, the exact mechanisms of the disease are unknown. Recent investigations have reported some structural and functional abnormalities on left temporal lobe of the brain [2-4]. Schizophrenia is a complex disorder that its transmission is either polygenic or oligogenic. Genetic epidemiological data from family, twin and adoption studies have consistently implicated the importance of genetic factors in the development of schizophrenia [5]. Generally, schizophrenia is a complicated genetic disease which has multigenic transferring patterns. It has been hypothesized that schizophrenia associated with the deletion of 22q11 might show the properties of a contiguous gene syndrome and that in the general population (without deletion) synergistic interactions between physically linked genes could result in increased risk of the disease [5]. Three candidate genes on 22q11 have been postulated as being involved in such a synergistic effect: proline dehydrogenase $(P R O D H)$, catechol-O-methyl transferase (COMT)

(C) 2019 Moghadam F. H. et al. This is an open-access article distributed under the terms of the Creative Commons Attribution License, which permits unrestricted use, distribution, and reproduction in any medium, provided the original author and source are credited. 
and $\mathrm{ZDHHC8}$ [5]. Proline dehydrogenase gene is one of the most important genes involved in the disease development [6]. This gene, which is highly expressed in the brain, expresses a protein named proline dehydrogenase (oxidase or POX) that catalysis the first stage of proline catabolism (changing pyroline to $\Delta-1$ pyroline-5- carboxylate). Pyroline-5carboxylate (P5C) then converts to glutamate or $\gamma$-aminobutyric acid [7], which are critically implicated in the pathophysiology of schizophrenia. Therefore, polymorphisms or mutations in this gene can reduce the activity of proline dehydrogenase enzyme and subsequently cause hyperprolinemia type I and increased risk of schizophrenia.

Evidences revealed an association between polymorphisms in $P R O D H$ and increased risk of schizophrenia [8]. Some studies showed that $P R O D H$ gene mutations may increase the activity of this enzyme. On the other hand, some mutations may decrease the expression of this enzyme and consequently cause an increase in the blood proline level, resulting in hyperprolinemia type I and schizophrenia [9]. There are some evidences that indicate several mutations in this gene can lead to its hyperactivity and overexpression and consequently increased catabolism of plasma proline and depletion of its plasma levels. Therefore, this data indicates a significant association between different types of polymorphisms or mutation and increased risk of schizophrenia in a population. In this study, we tried to confirm this association in a group of Iranian population. Here, we evaluated for the first time whether three polymorphisms G1496A, G758A and $\mathrm{C} 1482 \mathrm{~T}$ in $\mathrm{PRODH}$ gene are related to increased risk of schizophrenia in the Iranian population.

\section{Materials and Methods}

Patients and Methods. A total of 263 patients with schizophrenia (including 145 female and 118 male, aged 18-60 years) were entered into the study from psychiatry hospitals and clinics in Tehran (from 2012 to 2014). These patients were diagnosed according to the Diagnostic and Statistical Manual of Mental Disorders, Fourth Edition (DSM-IV), and their illness was confirmed by psychiatrists. Furthermore, 278 healthy individuals, with age-matched to the patient group, were also entered into the study All participants signed written informed consent. Patients with chronic diseases such as infectious diseases, diabetes, cancer, and other abnormalities other than schizophrenia were excluded from the study. Samples collection has been performed from 2013 to 2018. We analyzed three SNPs present on the PRODH gene, including G1496A, G758A and C1482T. Their chromosomal orders are as follows: rs382155-rs588609-rs450046, respectively. The genotyping of SNPs were performed by PCR-based restriction fragment length polymorphism (RFLP) analysis. For all participants, blood samples (5-8 ml) were obtained and collected in EDTA- containing tubes. Genomic DNA used for PCR amplification was extracted from the whole blood sample using a manual DNA extraction procedure. Confirmations of purified DNA were estimated by the Nanodrop set at 260/280 nm. For amplifying of genes were designed one pair primers for the each SNP genotyping (by oligo7 software), and PCR reaction was accomplished for amplifying exons 3 and 11. Genotypes were determined by RFLP with proper restriction enzymes. PCR amplicons were digested with BglI, StuI and FokI restriction enzymes (Fermentas company), respectively, and transferred on agarose gel (4\%). The primers used for PCR included: 5'-GCCCATCCTCACCCACACCTGC-3' (forward) and 5'-TAGCCGATCTCTGCCGCACG-3' (reverse) for amplification of the exon 11 (1496G/A), 5'-GTGTTTGGAGCTGTGCTCAG-3' (forward) and 5'-CTCAGGCTGGGACATGGCAG-3' (reverse) for amplification of the exon $3(758 \mathrm{G} / \mathrm{A})$ and $5^{\prime}$-GCCCTGTATCCCTGCAC-3' (forward), 5'-ACCTCCATCACGGGGCCA-3' (reverse) for amplification of the exon $11(1482 \mathrm{C} / \mathrm{T})$. The PCR amplification was performed in a $25-\mu 1$ reaction volume containing $10 \mathrm{mM}$ Tris-HCl (pH 8.3), $50 \mathrm{mM} \mathrm{KCl}, 1.5 \mathrm{mM}$ $\mathrm{MgCl}_{2}, 0.001 \%(\mathrm{w} / \mathrm{v})$ gelatin, $200 \mu \mathrm{M}$ of each dNTP, $0.4 \mu \mathrm{M}$ of each primer, 1.0 unit of Taq DNA polymerase, and 30-50 ng of genomic DNA. The conditions used for PCR amplification were as follow: the thermal cycling program for $1496 \mathrm{G} / \mathrm{A}$ (exon 11) consisted of activation of Taq DNA polymerase at $95^{\circ} \mathrm{C}$ for $5 \mathrm{~min}, 30$ cycles at $95^{\circ} \mathrm{C}$ for $1 \mathrm{~min}$ and at $63^{\circ} \mathrm{C}$ for $1 \mathrm{~min}$ and at $72{ }^{\circ} \mathrm{C}$ for $40 \mathrm{sec}$ and final extension at $72{ }^{\circ} \mathrm{C}$ for $7 \mathrm{~min}$. The thermal cycling program for $758 \mathrm{G} / \mathrm{A}$ (exon 3) consisted of activation of Taq DNA polymerase at $94{ }^{\circ} \mathrm{C}$ for $3 \mathrm{~min}, 15$ cycles at $95{ }^{\circ} \mathrm{C}$ for $30 \mathrm{sec}$ and $65^{\circ} \mathrm{C} 45 \mathrm{sec}\left(-1{ }^{\circ} \mathrm{C} /\right.$ cycle $)$ and $72{ }^{\circ} \mathrm{C}$ $30 \mathrm{sec}$ and 20 cycles at $94{ }^{\circ} \mathrm{C}$ for $30 \mathrm{sec}, 50^{\circ} \mathrm{C}$ for $45 \mathrm{sec}, 72{ }^{\circ} \mathrm{C}$ for $30 \mathrm{sec}$ and final extension at $72{ }^{\circ} \mathrm{C}$ for $7 \mathrm{~min}$ and finally, for amplifying of $1482 \mathrm{C} / \mathrm{T}$ was executed activation of Taq DNA polymerase at $95^{\circ} \mathrm{C}$ for $5 \mathrm{~min}, 30$ cycles at $95^{\circ} \mathrm{C}$ for $1 \mathrm{~min}$ and at $61^{\circ} \mathrm{C}$ for $1 \mathrm{~min}$ and at $72{ }^{\circ} \mathrm{C}$ for $1.15 \mathrm{~min}$ and final exten- 
sion at $72{ }^{\circ} \mathrm{C}$ for $7 \mathrm{~min}$. A $15-\mu 1$ aliquot of the PCR products was completely digested with 6-8 units of restriction enzymes and then separated on an agarose gel followed by ethidium bromide staining.

Statistical analysis. The Hardy-Weinberg equilibrium was checked by the goodness-of-fit chi-square $\left(\mathrm{X}^{2}\right)$ test for the genotypic distributions of SNPs studied. Allelic and haplotype association and quantitative trait analysis were executed by the SPSS 16.0 program. The $P$ value was set at 0.05 for significance levels.

\section{Results and Discussion}

Risk of outbreak schizophrenia in relation to $P R O D H$ gene and respective SNP markers. We considered three SNP markers on $P R O D H$ gene, including G1496A, G758A and C1482T. The $\mathrm{X}^{2}$ goodness-fit test showed that the genotypic distributions of two SNPs were not deviated from Hardy-Weinberg equilibrium either in the patient group $\left(\mathrm{X}^{2}=4: 78, \mathrm{df}=5, P=0: 443\right)$ or in the control group $\left(X^{2}=3: 86, d f=5, P=0: 569\right)$. Genotyping for G1496A polymorphism was determined using of BglI restriction enzyme. Fig. 1 shows a cut pattern in this polymorphism after using BglI restriction enzyme. In individuals with wild type homozygote genotype (GG), we observed a cut pattern with 3 bands, including 210, 50 and $24 \mathrm{bp}$, on agarose gels and for individuals with heterozygote genotype (GA) 4 bands, including, 284, 210, 50 and 24 bp were observed. In recessive homozygotes with AA genotype, a 284 bp sharp band was found. 14 individuals with AA genotype were found in the patient group, while we didn't find persons with AA genotype in the control group. There were 32 GA genotypes in the patient group, while there were 4 GA genotypes in control group. Results of statistical analysis for this SNP marker are shown in Table 1. Therefore, SNP G1496A may be effective in the incidence of the disease since $P$ value was $<0.01$ (Table 2).

Genotyping for G758A polymorphism in individuals was determined by using of StuI restriction enzyme. There was any cut site for StuI enzyme in individuals with wild type homozygote genotype (GG), therefore, we observed a cut pattern with 1 band at $240 \mathrm{bp}$. For individuals with heterozygote genotype (GA), we observed 3 bands at 240, 160, 80 bp. Also, in recessive homozygotes with AA genotype, two bands at 160 and 80 bp were observed. Fig. $2(a, b)$ shows cut patterns after using StuI. There were 2 individuals with AA genotype in the patient group but there were 4 AA genotypes in the control group. Also, 24 GA genotypes were observed in the patient group, while these numbers were 18 GA genotypes in control group. However, there was no significant association between G758A polymorphism and the incidence of schizophrenia $(P=0.241)$ (Table 2).

FokI restriction enzyme was applied for C1482T polymorphism genotyping after PCR am-

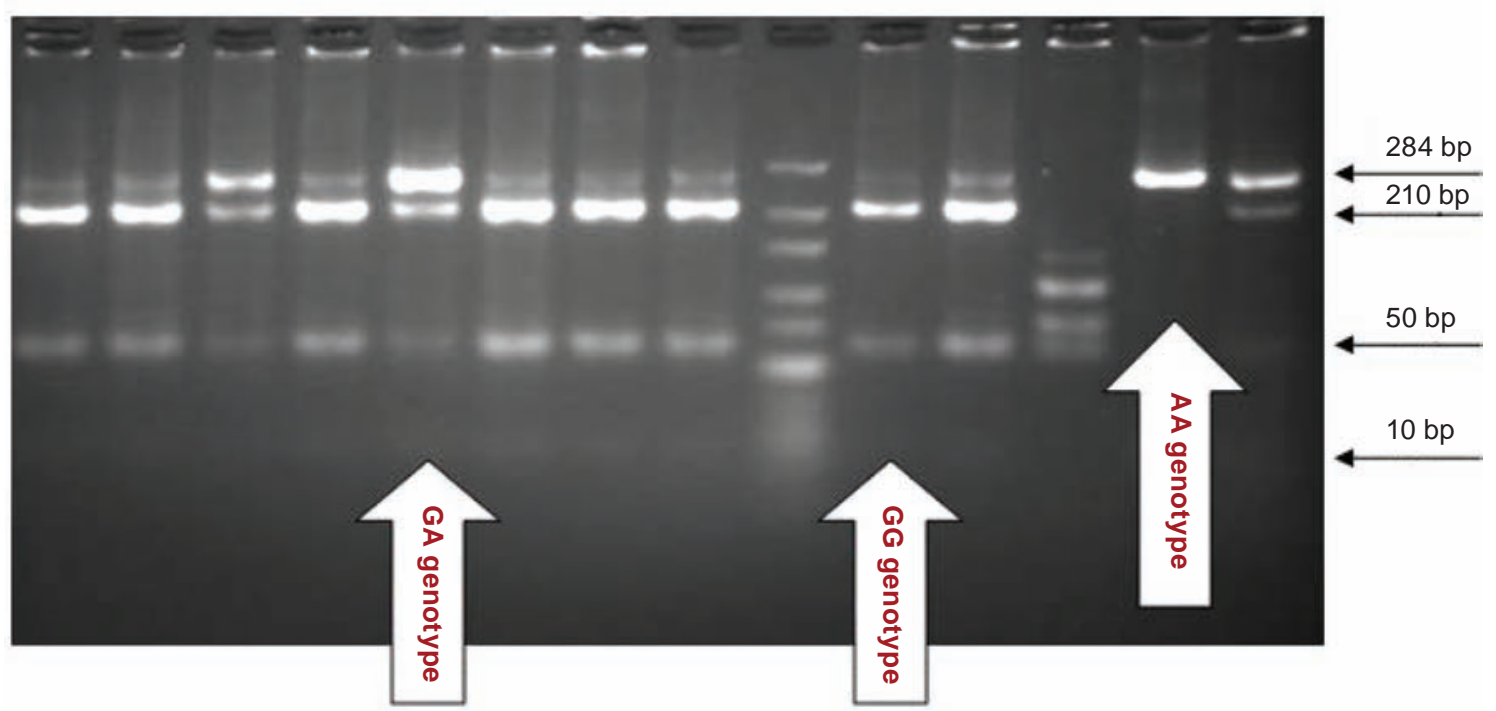

Fig. 1. Digestion with BglI restriction enzyme. The GG genotype displayed three bands, at 210, 50 and 24 (it is seen unclearly). The GA genotype displayed 4 bands, at 284, 210, 50 and $240 \mathrm{bp}$. The AA genotype showed 1 band at $284 \mathrm{bp}$ 
Table 1. Prevalence of the PRODH 758G/A polymorphisms in controls and schizophrenic patients; odds ratios (OR) with $95 \%$ confidence intervals $(95 \%$ CI) were determined to estimate the risk of schizophrenia

\begin{tabular}{c|c|c|c|c|c|c|c}
\hline \multirow{2}{*}{$\begin{array}{c}\text { Genotype } \\
\text { 758G/A }\end{array}$} & \multicolumn{2}{|c|}{ Controls $(N=278)$} & \multicolumn{2}{|c|}{ Patients $(N=263)$} & \multirow{2}{*}{ OR } & \multirow{2}{*}{$(95 \% \mathrm{CI})$} & \multirow{2}{*}{$P$ - value } \\
\cline { 2 - 5 } & Number & $\%$ & Number & $\%$ & & & \\
\hline 758GG & 256 & 51.9 & 237 & 48.1 & 1.38 & $0.94-2.63$ & \\
758GA & 18 & 42.9 & 24 & 57.1 & 1.21 & $0.89-1.55$ & 0.241 \\
$758 \mathrm{AA}$ & 4 & 66.7 & 2 & 33.3 & 1.17 & $0.92-1.76$ & \\
\hline
\end{tabular}

Ta ble 2. Prevalence of the PRODH 1496G/A polymorphisms in controls and schizophrenic patients; odds ratios (OR) with 95\% confidence intervals $(95 \% \mathrm{CI})$ were determined to estimate the risk of schizophrenia

\begin{tabular}{c|ccc|c|c|c|c}
\hline \multirow{2}{*}{$\begin{array}{c}\text { Genotype } \\
\text { 1496G/A }\end{array}$} & \multicolumn{2}{|c|}{ Controls $(N=278)$} & \multicolumn{2}{c|}{ Patients $(N=263)$} & \multirow{2}{*}{ OR } & \multirow{2}{*}{$(95 \% \mathrm{CI})$} & \multirow{2}{*}{$P$ - value } \\
\cline { 2 - 5 } & Number & $\%$ & Number & $\%$ & & & \\
\hline 1496GG & 274 & 55.8 & 217 & 44.2 & 1.25 & $0.97-2.82$ & \\
1496GA & 4 & 11.1 & 32 & 88.9 & 1 & $0.90-1.75$ & 0.001 \\
1496AA & 0 & 0.0 & 14 & 100.0 & 1.15 & $0.88-2.16$ & 0.001 \\
\hline
\end{tabular}

plification of these exons. The results of enzyme cut patterns by FokI showed that individuals with wild type homozygote genotype (CC) had two cut sites and 3 segments were observed at 60, 100 and 125 bp (Fig. 3). In recessive homozygote genotype (TT), one cut site was added and segment 125 bp was broken to 2 segments of 100 and $25 \mathrm{bp}$. Therefore, in this condition, we observed 3 bands, including, 25, 60 and 100 bp (2 bands were overlapped). Finally, for heterozygote genotype (CT), 4 bands of 25, 60, 100 and 125 bp were observed. As a whole, TT recessive genotype was found in 5 patients group but not control group. Also, 36 individuals with CT heterozygote genotype were found in patients group and there were only 3 individuals with this genotype in control group. According to our results, these polymorphisms can be correlated with schizophrenia outbreak in this population since the $P$ value was $<0.01$ (Table 3).

Combinational effect of $1496 \mathrm{G} / \mathrm{A}, 758 \mathrm{G} / \mathrm{A}$ and C1482T with the risk of schizophrenia. We analyzed the co-effect of the presence of three alleles in these positions on $P R O D H$ gene, simultaneously, and their correlation with schizophrenia. After determining frequency for each of genotypes in every case, we tried to determine whether a compound of three alleles in these polymorphisms on $P R O D H$ gene could be effective on schizophrenia incidence in our population. In other words we assessed the relationship between possible haplotypes and schizophrenia on our population. Table 4 shows the frequencies of compound genotypes within the group of controls and patients. According to the chi-squared test, there was a significant association between $P R O D H$ $1496 \mathrm{G} / \mathrm{A}, 758 \mathrm{G} / \mathrm{A}$ and $1482 \mathrm{C} / \mathrm{T}$ variants within the group of patients compared to controls. The activity of alleles in the $P R O D H$ genotype combinations was associated with an increased risk of schizophrenia. Based on these data, AAT, AAC and GAT haplotype carriers were significantly related to schizophrenia in a comparison of the patient and control groups.

Schizophrenia is a mental disorder which is characterized by a breakdown of thought processes and poor emotional responsiveness. It most commonly manifests itself as auditory hallucinations, paranoid or disorganized speech and thinking $[3,4]$. Genetics, environment, neurobiology, psychological and social processes appear to be important synergetic factors [1, 10]. Regard to different study, it seems $P R O D H$ is as an important genetic factor in relation to susceptibility to schizophrenia incidence. In the current study, we examined the hypothesis that the $P R O D H$ gene is associated with schizophrenia in our population, using $3 \mathrm{SNPs} /$ haplotypes in this gene. We evaluated G1496A, G758A and C1482T in PRODH in Iranian population (especially west and south of the country).

Previously, we analyzed some polymorphisms in PRODH, CLDN5 and ApoA1 genes and their correlations with schizophrenia in Iranian population. Also, we studied changes in plasma levels of proline amino acid, ApoA1 protein and IgM immunoglobu- 
$a$

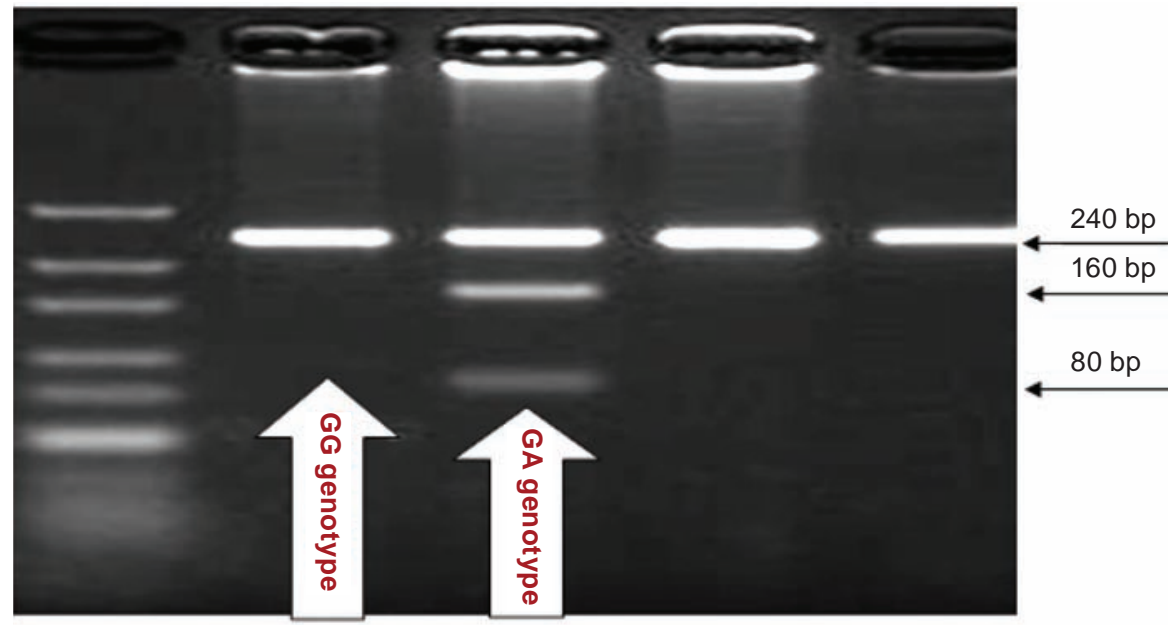

$\boldsymbol{b}$

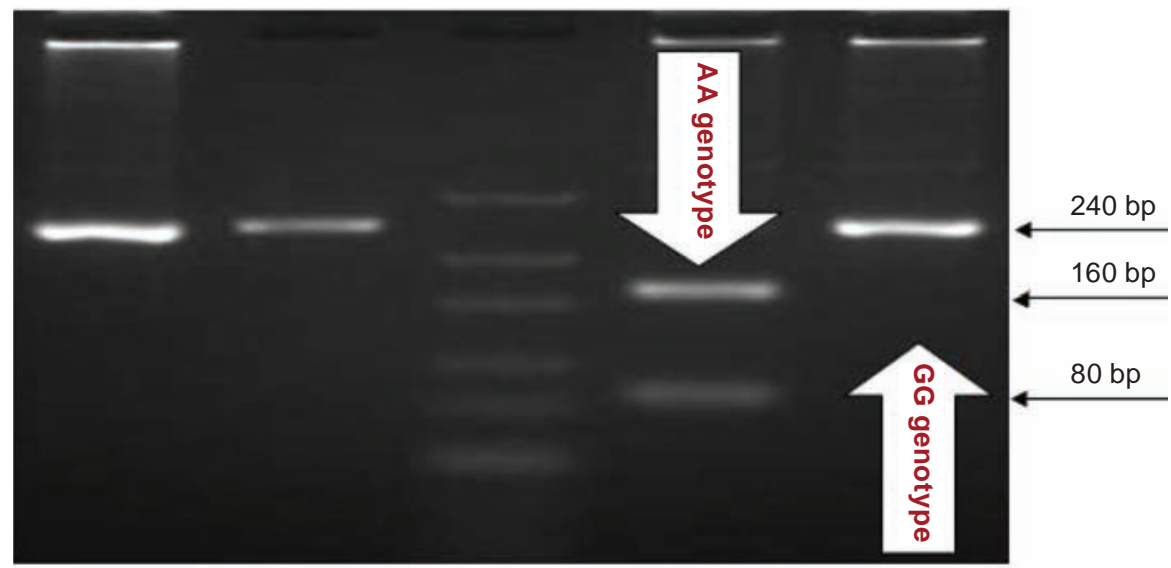

Fig. 2. Digestion with StuI restriction enzyme. (a): The GG genotype displayed one band, at 240 bp. The GA genotype displayed 3 bands, at 80, 160 and 240 bp. (b): The AA genotype showed 2 bands at 80 and 160 bp. The GG genotype displayed one band, at $240 \mathrm{bp}$

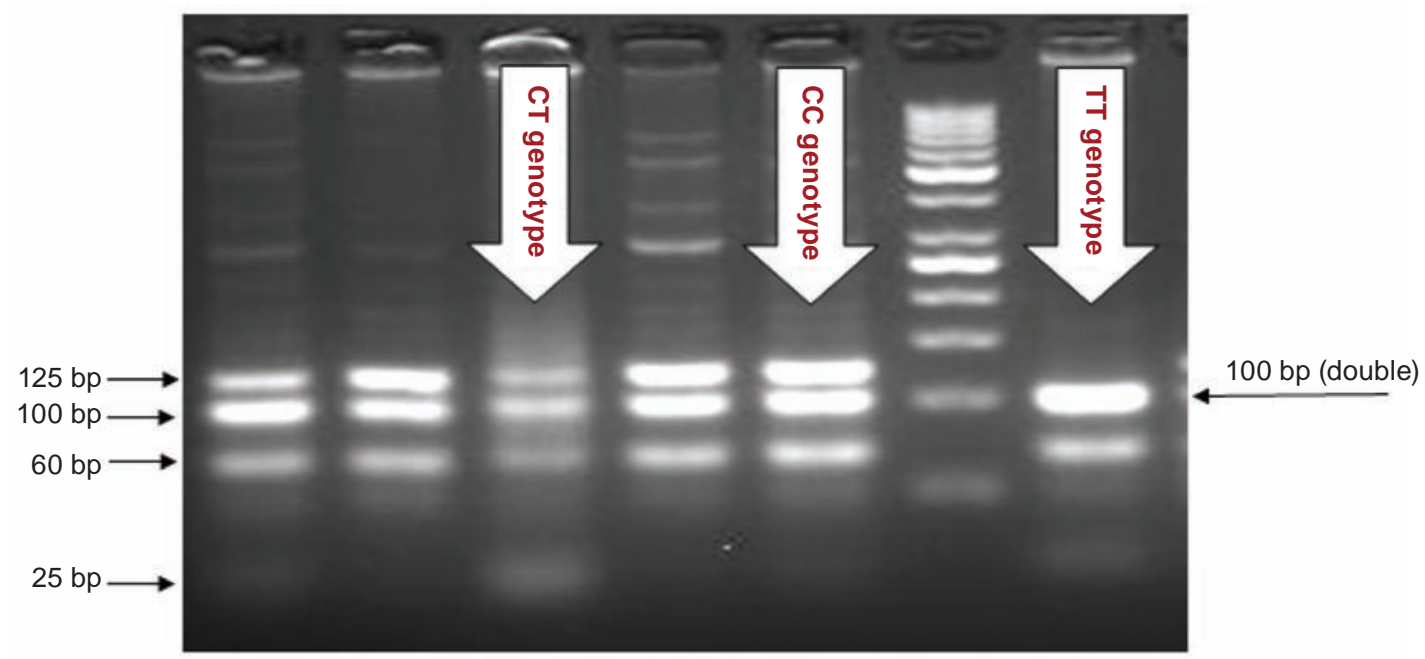

Fig. 3. Digestion with FokI restriction enzyme. The CC genotype displayed 3 bands, at 60, 100 and 120 bp. The CT genotype displayed 4 bands, at 25, 60, 100 and 125 bp. The TT genotype showed 3 bands at 25, 60 and 100 bp (2 bands overlapped) 
Ta b le 3. Prevalence of the PRODH 1482C/T polymorphisms in controls and schizophrenic patients; odds ratios (OR) with $95 \%$ confidence intervals $(95 \%$ CI) were determined to estimate the risk of schizophrenia

\begin{tabular}{c|c|c|c|c|c|c|c}
\hline \multirow{2}{*}{$\begin{array}{c}\text { Genotype } \\
1482 \mathrm{C} / \mathrm{T}\end{array}$} & \multicolumn{2}{|c|}{ Controls $(N=278)$} & \multicolumn{2}{c|}{ Patients $(N=263)$} & \multirow{2}{*}{ OR } & \multirow{2}{*}{$(95 \% \mathrm{CI})$} & \multirow{2}{*}{$P$-value } \\
\cline { 2 - 5 } & Number & $\%$ & Number & $\%$ & & & \\
\hline $1482 \mathrm{CC}$ & 275 & 55.3 & 222 & 44.7 & 1.11 & $0.94-2.85$ & \\
$1482 \mathrm{CT}$ & 3 & 7.7 & 36 & 92.3 & 1 & $0.93-1.95$ & 0.002 \\
$1482 \mathrm{TT}$ & 0 & 0.0 & 5 & 100 & 1.28 & $0.85-2.0$ & \\
\hline
\end{tabular}

Ta b le 4. Haplotype distribution of the PRODH gene

\begin{tabular}{c|c|c|c}
\hline Haplotype & Frequency in the controls & Frequency in the patients & $P$-value \\
\hline AAT & 0.139 & 0.285 & 0.01 \\
AAC & 0.196 & 0.381 & 0.008 \\
GAT & 0.152 & 0.296 & 0.009 \\
AGT & 0.315 & 0.354 & 0.125 \\
GGT & 0.225 & 0.332 & 0.095 \\
\hline
\end{tabular}

Variation alleles are marked in bold.

lin in relation to respective polymorphisms [11-14]. In previous studies, we reported $757 \mathrm{C} / \mathrm{T}, 1766 \mathrm{~A} / \mathrm{G}$, 1852G/A, 1945T/C PRODH polymorphisms were correlated to schizophrenia and ApoA1 polymorphisms had no correlation to the disease. Subsequently, we decided to continue our investigations with other polymorphisms on another group. In this current study, we selected study populations from the south and west regions of Iran with larger samples size of acute schizophrenia and control individuals. Since exon $11 P R O D H$ is known as a high risk region for the occurrence of functional mutations and polymorphisms [15-17], we examined two polymorphisms in this exon and also one polymorphism in exon 3.

In the $P R O D H$ G1496A polymorphism that has been located on exon 11, replacement of nucleotide A instead of nucleotide $G$ causes to replacement of amino acid arginine to histidine at position 431 in proline oxidase enzyme (POX). It seems that this change is effective on expression and function of POX and leads to decreasing of its function and subsequently, leads to increasing of proline amino acid in plasma and hyperprolinemia type I. Several investigations showed that it can reduce glutamate and $\gamma$-aminobutyric acid levels, as two important neurotransmitters in the brain and leads to schizophrenia [18-20]. Some studies investigated polymorphisms on this codon in different populations [15, 16, 21]. Our data have revealed 14 individuals by recessive homozygote variant (AA) in patient group, whereas this variant wasn't observed in control individuals (100\% AA variant in patient group). Furthermore, 32 cases by heterozygote variant (GA) were found in patients, whereas there were only were 4 individuals in controls (88.9\% GA genotype in patient group). These data indicate that allelic frequency of A variant in individuals with schizophrenia is significantly different compared to healthy individuals. Therefore, this codon may contribute to the occurrence of the disease in our society. In G758A polymorphism, which is located on exon 3 of $P R O D H$, naturally codes amino acid Arg at position 185 in proline oxidase enzyme. This polymorphism is enumerated as a silent variation in this gene but it seems that it is effective on the function of POX protein [22]. It has been reported that this polymorphism causes an increase in enzyme activity in blood and subsequently, it can decrease proline level in the blood. It has also been observed that this change can increase glutamate level in the brain and causes increased risk of schizophrenia [19, 23]. According to our results, there were 2 individuals with AA genotype in patient group, but there were 4 persons with AA genotype in control group (57.1\% in patient group and $42.9 \%$ in control). Also, there were 24 persons with GA genotype in the patient group, while 18 subjects in control group had GA genotype (66.7\% AA genotype in control group). Allelic frequency of A variant in control group was more than usual extent that 
could name it as an effective genetic factor associated with schizophrenia in our population, therefore, we indicated that there was no significant association between G758A polymorphism and the incidence of schizophrenia $(P=0.241)$. C1482T polymorphism is located in exon11 in PRODH gene and normally is coded for Asparagine amino acid at position of 426 of PRODH enzyme. This polymorphism $(\mathrm{C}>\mathrm{T})$ is probably enumerated as a silent variation because this substitution leads to exchanging of a codon to another codon for Asparagine, but there is increasing evidence supporting the notion that synonymous SNPs are capable of alterations in protein amounts, structures, or function. Some studies reported the occurrence of $\mathrm{C} 1482 \mathrm{~T}$ in $P R O D H$ leads to decreasing of the enzyme activity and consequently increased risk of schizophrenia [21, 22].

Statistical analysis for this polymorphism showed that there were 36 heterozygote T allele carriers in patient group (92.3\%), while it was found in 3 controls (7.7\%). More importantly, there were 5 patients with TT recessive variants (100\%) and there was no individual with this genotype in controls. On the other hand, there was a significant correlation between allelic frequency ( $\mathrm{T}$ variant) and the outbreak of schizophrenia in our population. In this study, we also assayed haplotype blocks in relation to the disease in population. Our results showed that AAT, AAC and GAT blocks (variant alleles are bold), from the respective statistical analysis, were related to schizophrenia. In another study on a Greek/Caucasian population, a significant association was reported between haplotypes consisting of three SNPs: 1945T/C, 1766A/G and 1852G/A with schizophrenia. They indicated that the alleles 1945C, 1766A and 1852G were over transmitted in schizophrenia patients [17, 24, 25]. Li et al. reported that PRODH 1945C-1852A haplotype was an important determinant of executive functions in schizophrenia patients [26]. We also reported a significant correlation between haplotypes consisting of $757 \mathrm{C} / \mathrm{T}$, $1852 \mathrm{G} / \mathrm{A}$ and 1766A/G [11]. A series of investigations are being conducted by our research team to consider the effects of PRODH, COMT, CLDN5, and ApoA1 polymorphisms on schizophrenia. Determining of genetic transmission patterns of schizophrenia in Iranian population is the most important aim of our investigations and in continuously, if it is possible, we are going to suggest the best drug construction for these patients based on genetic pattern. Also, as regards there was no sufficient molecular biomarker (s) for pre-diagnosis of schizophrenia, nowadays, it looks these studies are useful for determining proper genetic marker(s) for this object.

Our data have revealed that $P R O D H$ can be an important susceptible gene in relation to the schizophrenia risk in Iranian individuals. Also, it can be used for the detection of the disease as a genetic marker. However, it is essential to continue more extensive studies on different population and with other candidate genes and maybe by using stronger methodology.

Acknowledgements. The authors are grateful of colleagues in Enzyme Technology Lab., Genetics \& Metabolism Research Group, Pasteur Institute of Iran, Tehran, Iran. Also, we thank all of the persons who helped us to collect specimens, especially RAZI hospital and psychiatric clinics, especial Shiraz and other southern and western cities.

Conflict of interest. Authors have completed the Unified Conflicts of Interest form at http://ukrbiochemjournal.org/wp-content/uploads/2018/12/ coi_disclosure.pdf and declare no conflict of interest.

\section{ПОЛІМОРФІЗМ ГЕНА ПРОЛІНДЕГІДРОГЕНАЗИ (PRODH) I РИЗИК ШИЗОФРЕНIÏ В ІРАНСЬКИХ ПОПУЛЯЦІЯХ}

\section{F. H. Moghadam ${ }^{1}$, Z. H. A. Mehrabani ${ }^{2}$, M. Amounajaf ${ }^{3}$, S. Rahmanzadeh ${ }^{3}$, F. Ghasemvand ${ }^{3}$, A. S. Samghabadi ${ }^{3}$, A. Nejadmoghaddam ${ }^{3}$, E. Omidinia ${ }^{3 凶}$ \\ ${ }^{1}$ Department of Traditional Medicine, School of Traditional Medicine, Shahid Beheshti \\ University of Medical Sciences, Tehran, Iran; ${ }^{2}$ Department of Clinical Biochemistry and Laboratory Medicine, Tabriz University of Medical Sciences, Tabriz, Iran;}

${ }^{3}$ Enzyme Technology Lab., Genetics \& Metabolism Research Group, Pasteur Institute of Iran, Tehran, Iran; 凶e-mail: saeed_r81@yahoo.com or2000.spss@gmail.com

Шизофренія - це спадковий психічний розлад, який може бути спричиненим мутаціями або однонуклеотидним поліморфізмом (SNP) різних генів. Ген проліндегідрогенази $(\mathrm{PRODH})$ $\epsilon$ одним з найважливіших генів, який може бути пов'язаний $з$ підвищеним ризиком розвитку шизофренії в деяких популяціях. Було вивчено 
вплив поліморфізмів гена $P R O D H$ на частоту випадків шизофренії в населення Ірану. Для цього було проведено аналіз 3 маркерів SNP, таких як G1496A, G758A i C1482T, у 263 хворих на шизофренію і 278 здорових людей (контрольна група). Дослідження проводили методом поліморфізму довжин рестрикційних фрагментів (RFLP) за допомогою полімеразних ланцюгових реакцій. Статистичний аналіз даних було виконано за допомогою програмного забезпечення SPSS $(16,0)$. Показано, що поліморфізм G1496A і C1482T у пацієнтів був значно вищим, ніж у контрольній групі, також встановлено вірогідну кореляцію між виникненням цих поліморфізмів і шизофренією в популяції $(P<0,001)$. Однак не було виявлено взаємозв'язку між G758A в гені PRODH і шизофренією. Аналіз гаплотипів показав, що алельні варіації АAT, АAC і GAT вірогідно корелювали з випадками шизофренії. Ген $P R O D H$ можна розглядати як один із важливих генів, які причетні до розвитку шизофренії серед населення Ірану.

Ключов і слов а: ген проліндегідрогенази, поліморфізм, поліморфізм довжин рестрикційних фрагментів (RFLP), шизофренія.

\section{References}

1. Karayiorgou M, Gogos JA. A turning point in schizophrenia genetics. Neuron. 1997; 19(5): 967-979.

2. Chow EW, Zipursky RB, Mikulis DJ, Bassett AS. Structural brain abnormalities in patients with schizophrenia and 22q11 deletion syndrome. Biol Psychiatry. 2002; 51(3): 208-215.

3. Kirkpatrick B, Buchanan RW, Breier A, Carpenter WT Jr. Depressive symptoms and the deficit syndrome of schizophrenia. J Nerv Ment Dis. 1994; 182(8): 452-455.

4. Andreasen NC, Carpenter WT Jr, Kane JM, Lasser RA, Marder SR, Weinberger DR. Remission in schizophrenia: proposed criteria and rationale for consensus. Am J Psychiatry. 2005; 162(3): 441-449.

5. Karayiorgou M, Gogos JA. The molecular genetics of the 22q11-associated schizophrenia. Brain Res Mol Brain Res. 2004; 132(2): 95-104.

6. McDermid HE, Morrow BE. Genomic disorders on 22q11. Am J Hum Genet. 2002; 70(5): 10771088.
7. Phang JM, Hu C, Valle D. Disorders of proline and hydroxyproline metabolism. Metab Mol Bases Inherit Dis. 2001; 3: 1821-1838.

8. Fallin MD, Lasseter VK, Avramopoulos D, Nicodemus KK, Wolyniec PS, McGrath JA, Steel G, Nestadt G, Liang KY, Huganir RL, Valle D, Pulver AE. Bipolar I disorder and schizophrenia: a 440-single-nucleotide polymorphism screen of 64 candidate genes among Ashkenazi Jewish case-parent trios. Am J Hum Genet. 2005; 77(6): 918-936.

9. Humbertclaude V, Rivier F, Roubertie A, Echenne B, Bellet $\mathrm{H}$, Vallat C, Morin D. Is hyperprolinemia type I actually a benign trait? Report of a case with severe neurologic involvement and vigabatrin intolerance. $J$ Child Neurol. 2001; 16(8): 622-623.

10. Aleman A, Kahn RS, Selten JP. Sex differences in the risk of schizophrenia: evidence from metaanalysis. Arch Gen Psychiatry. 2003; 60(6): 565571.

11. Ghasemvand F, Omidinia E, Salehi Z, Rahmanzadeh S. Relationship between polymorphisms in the proline dehydrogenase gene and schizophrenia risk. Genet Mol Res. 2015; 14(4): 11681-11691.

12. Ghasemvand F, Rahman Zadeh S, Salehi Z, Fakour Y, Heidari Keshel S, Omidinia E. Association of $757 \mathrm{C} / \mathrm{T}$ polymorphismin PRODH gene with Schizophrenia in Iranian population. J Paramed Sci. 2013; 4(1): 97-104.

13. Heidari Keshel S, Sadough N,Omidinia S, Rahmanzadeh S. Quantitative determination of immunoglobulin IgM and apolipoprotein A1 in schizophrenia population. J Paramed Sci. 2013; 4(1): 107-111.

14. Rahman Zadeh A, Mohammadi HS, Karimipour M, Heidari Keshel S, Omidinia E. Investigation of genetic association between $P R O D H$ gene and schizophrenia in Iranian population. J Paramed Sci. 2012; 3(1): 7-16.

15. Bender HU, Almashanu S, Steel G, Hu CA, Lin WW, Willis A, Pulver A, Valle D. Functional consequences of PRODH missense mutations. Am J Hum Genet. 2005; 76(3): 409-420.

16. Liu H, Abecasis GR, Heath SC, Knowles A, Demars S, Chen YJ, Roos JL, Rapoport JL, Gogos JA, Karayiorgou M. Genetic variation in the 22q11 locus and susceptibility to schizophrenia. Proc Natl Acad Sci USA. 2002; 99(26): 16859-16864. 
17. Liu H, Heath SC, Sobin C, Roos JL, Galke BL, Blundell ML, Lenane M, Robertson B, Wijsman EM, Rapoport JL, Gogos JA, Karayiorgou $M$ Genetic variation at the 22q11 PRODH2/DGCR6 locus presents an unusual pattern and increases susceptibility to schizophrenia. Proc Natl Acad Sci USA. 2002; 99(6): 3717-3722.

18. Hoogendoorn B, Coleman SL, Guy CA, Smith SK, O'Donovan MC, Buckland PR. Functional analysis of polymorphisms in the promoter regions of genes on 22q11. Hum Mutat. 2004; 24(1): 35-42.

19. Jacquet H, Raux G, Thibaut F, Hecketsweiler B, Houy E, Demilly C, Haouzir S, Allio G, Fouldrin G, Drouin V, Bou J, Petit M, Campion D, Frébourg T. PRODH mutations and hyperprolinemia in a subset of schizophrenic patients. Hum Mol Genet. 2002; 11(19): 22432249.

20. Williams NM, O'Donovan MC, Owen MJ. Chromosome 22 deletion syndrome and schizophrenia. Int Rev Neurobiol. 2006; 73: 1-27.

21. Sauna ZE, Kimchi-Sarfaty C, Ambudkar SV, Gottesman MM. Silent polymorphisms speak: how they affect pharmacogenomics and the treatment of cancer. Cancer Res. 2007; 67(20): 9609-9612.

22. Kempf L, Nicodemus KK, Kolachana B, Vakkalanka R, Verchinski BA, Egan MF, Straub RE, Mattay VA, Callicott JH,
Weinberger DR, Meyer-Lindenberg A. Functional polymorphisms in PRODH are associated with risk and protection for schizophrenia and fronto-striatal structure and function. PLoS Genet. 2008; 4(11): e1000252.

23. Jacquet H, Demily C, Houy E, Hecketsweiler B, Bou J, Raux G, Lerond J, Allio G, Haouzir S, Tillaux A, Bellegou C, Fouldrin G, Delamillieure $\mathrm{P}$, Ménard JF, Dollfus S, D'Amato T, Petit M, Thibaut F, Frébourg T, Campion D. Hyperprolinemia is a risk factor for schizoaffective disorder. Mol Psychiatry. 2005; 10(5): 479-485.

24. Li T, Ma X, Sham PC, Sun X, Hu X, Wang Q, Meng H, Deng W, Liu X, Murray RM, Collier DA. Evidence for association between novel polymorphisms in the PRODH gene and schizophrenia in a Chinese population. Am J Med Genet B Neuropsychiatr Genet. 2004; 129B(1): 13-15.

25. Roussos P, Giakoumaki SG, Bitsios P. A risk PRODH haplotype affects sensorimotor gating, memory, schizotypy, and anxiety in healthy male subjects. Biol Psychiatry. 2009; 65(12): 1063-1070.

26. Li T, Ma X, Hu X, Wang Y, Yan C, Meng H, Liu X, Toulopoulou T, Murray RM, Collier DA. PRODH gene is associated with executive function in schizophrenic families. Am J Med Genet B Neuropsychiatr Genet. 2008; 147B(5): 654-657. 